\title{
GAMBARAN PERAWATAN GIGI DAN MULUT PADA BULAN KESEHATAN GIGI NASIONAL PERIODE TAHUN 2012 DAN 2013 DI RSGMP UNSRAT
}

\author{
${ }^{1}$ Clana A. C. Soplantila, \\ ${ }^{2}$ Michael A. Leman, \\ ${ }^{2}$ Juliatri
}

\author{
${ }^{1}$ Kandidat Skripsi Program Studi Pendidikan Dokter Gigi Fakultas Kedokteran \\ ${ }^{2}$ Program Studi Pendidikan Dokter Gigi Fakultas Kedokteran \\ Universitas Sam Ratulangi Manado \\ E-mail: ayusoplantila2411@gmail.com
}

\begin{abstract}
Tooth and mouth is the entry gateway of bacteria that can damage the health of other organs. Indonesian dentists in order to improve the health of society is have to act as motivators, educators, and providers of health services (preventive, promotive, curative, and rehabilitative). National Dental Health Month (BKGN) is a social activity that is expected to motivate the citizens of Manado and surrounding communities in order to be aware of the importance of prevention and early dentalcare. This was a descriptive retrospective study. Since the data of 2012 were incomplete, we only used data of 2013. There were 1964 patients in 2013; all medical records were filed completely. Dental and oral cares were the highest in the age group $\leq 20$ years. There were more women (63.14\%) than men (36.86\%). Based on the type of jobs, the majority of patients (59.98\%) were students. Based on the type of maintenance carried out most of them (34.88\%) were scaling.
\end{abstract}

Keywords: BKGN, oral health, scaling

\begin{abstract}
Abstrak: Gigi dan mulut merupakan pintu gerbang masuknya bakteri sehingga dapat mengganggu kesehatan organ tubuh lainnya. Dokter gigi di Indonesia dalam rangka meningkatkan derajat kesehatan masyarakat, wajib bertindak sebagai motivator, pendidik, dan pemberi pelayanan kesehatan (preventif, promotif, kuratif, dan rehabilitatif). Bulan kesehatan Gigi Nasional (BKGN) merupakan kegiatan bakti sosial yang diharapkan dapat memotivasi warga masyarakat Kota Manado dan sekitarnya agar kembali sadar akan pentingnya upaya pencegahan dan perawatan gigi sejak dini. Jenis penelitian ini bersifat deskriptif dengan pendekatan retrospektif. Populasi yang digunakan yaitu seluruh rekam medik pasien pada BKGN periode tahun 2012 dan 2013. Data rekam medik tahun 2012 tidak lengkap sehingga tidak digunakan. Data rekam medik tahun 2013 terdapat 1964 pasien yang diisi dengan lengkap. Hasil penelitian BKGN pada periode tahun 2013 berdasarkan kelompok umur menunjukkan perawatan gigi dan mulut lebih banyak pada kelompok umur $\leq 20$ tahun. Berdasarkan jenis kelamin didapatkan perempuan (63,14\%) lebih banyak dibandingkan lakilaki (36,86\%). Berdasarkan jenis pekerjaan mayoritas pasien yang berkunjung ialah pelajar/mahasiswa dengan persentase $59,98 \%$. Berdasarkan jenis perawatan yang dilakukan paling banyak ialah skeling sebesar 34,88\%.
\end{abstract}

Kata kunci: BKGN, perawatan gigi dan mulut, skeling

Kesehatan merupakan faktor penting dalam kehidupan manusia. Kesehatan gigi dan mulut merupakan bagian dari kesehatan secara umum yang perlu diperhatikan oleh masyarakat. Oleh karena itu, kesehatan gigi dan mulut pun harus sangat diperhatikan. 
Gigi dan mulut merupakan pintu gerbang masuknya bakteri sehingga dapat mengganggu kesehatan organ tubuh lainnya. Masalah karies gigi masih banyak dikeluhkan baik oleh anak-anak maupun dewasa dan tidak dapat dibiarkan hingga parah karena akan memengaruhi kualitas hidup mereka antara lain menyebabkan rasa sakit, ketidaknyamanan, infeksi akut dan kronis, gangguan makan dan tidur, serta memiliki risiko tinggi untuk dirawat di rumah sakit. ${ }^{1,2}$

Hasil riset tingkat kesadaran kesehatan gigi dan mulut di kalangan masyarakat Indonesia masih rendah. Riset Kesehatan Dasar (Riskesdas) 2013 menunjukkan angka DMF-T sebesar 4,6 dan di Sulawesi Utara angka tersebut mencapai 5,4, menunjukkan bahwa masyarakat Sulawesi Utara rata-rata memiliki kurang lebih lima gigi karies setiap orangnya. Hal ini mungkin dapat disebabkan oleh perilaku menyikat gigi yang benar pada masyarakat Sulawesi Utara masih rendah yaitu hanya mencapai 3,3\% dan proporsi penduduk yang berobat ke tenaga medis gigi hanya mencapai 7,3\%.

Bulan kesehatan Gigi Nasional (BKGN) merupakan kegiatan bakti sosial yang diharapkan dapat memotivasi warga masyarakat Kota Manado dan sekitarnya agar kembali sadar akan pentingnya upaya pencegahan dan perawatan gigi sejak dini. Kegiatan ini dilaksanakan dari tahun 2011 untuk memperingati hari kesehatan gigi dan mulut dunia yang jatuh pada tanggal 12 September. $^{2}$ Kegiatan ini berupa pemeriksaan dan pengobatan gigi gratis yang dilaksanakan di Rumah Sakit Gigi \& Mulut Pendidikan (RSGMP) Unsrat Manado yang dilangsungkan selama tiga hari berturut-turut oleh para tenaga dokter gigi yang bertugas di Program Studi Pendidikan Dokter Gigi (PSPDG) Unsrat dan di RSGMP Unsrat bekerjasama dengan tenaga medis dokter gigi anggota Persatuan Dokter Gigi Indonesia (PDGI) cabang Manado.

Berdasarkan uraian tersebut, maka penulis tertarik untuk melakukan penelitian survei tentang jumlah perawatan gigi dan mulut pada Bulan Kesehatan Gigi Nasional periode tahun 2012 dan 2013 di RSGMP Unsrat.

\section{BAHAN DAN METODE PENELITIAN}

Penelitian ini merupakan jenis penelitian deskriptif dengan menggunakan pendekatan retrospektif. Penelitian bertempat di Rumah Sakit Gigi dan Mulut Pendidikan Universitas Sam Ratulangi. Jalan Dr. Sutomo No. 03 kelurahan Pinasungkulan kecamatan Wenang kota Manado provinsi Sulawesi Utara pada bulan Juni - Juli 2015. Populasi pada penelitian ini yaitu seluruh rekam medik pasien pada BKGN periode tahun 20112 dan 2013 di RSGMP Unsrat. Teknik pengambilan sampel yang digunakan yaitu total sampling. Perawatan gigi dan mulut yaitu jenis perawatan gigi dan mulut yang dilakukan yang tertulis pada rekam medik saat BKGN periode tahun 2012 dan 2013.

\section{HASIL PENELITIAN}

Hasil penelitian menunjukkan bahwa dari 1964 pasien yang melakukan perawatan gigi dan mulut pada BKGN periode tahun 2013 di RSGMP Unsrat Manado berdasarkan jenis kelamin, persentase perempuan lebih besar berjumlah 36,86\% sedangkan laki-laki dengan persentase 63,14\%. Berdasarkan karakteristik umur pada periode BKGN tahun 2013 terdiri dari umur $\leq 20$ tahun berjumlah 1050 pasien, 21-30 tahun berjumlah 494 pasien, 31-40 tahun berjumlah 155 pasien, 41-50 tahun berjumlah 133 pasien, 51-60 tahun berjumlah 80 pasien, $>60$ tahun berjumlah 52 pasien.

Data pada Tabel 1 menunjukan terdapat jumlah pasien terbanyak pada umur $\leq 20$ tahun dengan persentase sebesar $53,46 \%$, selanjutnya pada rentang umur 2130 tahun dengan persentase $25,15 \%$, umur 31-40 tahun dengan persentase 7,89\%, umur 41-50 tahun dengan persentase 6,77\%, umur 51-60 tahun dengan persentase $4,08 \%$, dan yang paling sedikit yaitu pada umur $>60$ tahun dengan persentase 2,65\%. 
Tabel 1. Distribusi hasil penelitian berdasarkan karakteristik umur

\begin{tabular}{lcc}
\hline $\begin{array}{c}\text { Umur } \\
\text { (tahun) }\end{array}$ & $\mathrm{n}$ & $\%$ \\
\hline$\leq 20$ & 1050 & 53,46 \\
$21-30$ & 494 & 25,15 \\
$31-40$ & 155 & 7,89 \\
$41-50$ & 133 & 6,77 \\
$51-60$ & 80 & 4,08 \\
$>60$ & 52 & 2,65 \\
$\quad$ Jumlah & 1964 & 100 \\
\hline
\end{tabular}

Berdasarkan karakteristik jenis pada BKGN periode tahun 2013 terdiri dari 176 pencabutan gigi sulung, 305 pencabutan gigi permanen, 685 skeling, 135 penumpatan dengan resin komposit, 162 penumpatan dengan semen ionomer kaca (GIC), 33 fissure sealant, 64 aplikasi topikal fluor, 321 Dental Health Education, 14 penumpatan sementara, 69 screening, dan tidak ada yang melakukan penumpatan amalgam.

Tabel 2. Distribusi hasil penelitian berdasarkan karakteristik perawatan

\begin{tabular}{lcl}
\hline \multicolumn{1}{c}{ Jenis perawatan } & $\mathrm{n}$ & $\%$ \\
\hline Screening & 69 & 3,51 \\
DHE & 321 & 16,35 \\
Skeling & 685 & 34,88 \\
Penumpatan komposit & 135 & 6,87 \\
Penumpatan GIC & 162 & 8,25 \\
Penumpatan sementara & 14 & 0,71 \\
Fissure sealant & 33 & 1,68 \\
Aplikasi topikal fluor & 64 & 3,26 \\
Pencabutan gigi sulung & 176 & 8,96 \\
Pencabutan gigi permanen & 305 & 15,53 \\
Penumpatan amalgam & 0 & 0,00 \\
Jumlah & 1964 & 100 \\
\hline
\end{tabular}

Data pada Tabel 2 jenis perawatan diketahui jumlah responden dengan jenis perawatan skeling merupakan responden terbanyak dengan persentase 34,88\%, perawatan DHE dengan persentase $16,35 \%$, perawatan pencabutan gigi permanen dengan persentase $15,53 \%$, perawatan pencabutan gigi sulung dengan persentase $8,96 \%$, perawatan penumpatan GIC dengan persentase $8,25 \%$, perawatan penumpatan komposit dengan persentase 6,87\%, perawatan aplikasi topikal fluor dengan persentase 3,26\%, perawatan fissure sealant dengan persentase $1,68 \%$, dan yang paling sedikit yaitu jenis perawatan penumpatan sementara dengan persentase $(0,71 \%)$. Screening dengan persentase 3,51\%.

\section{BAHASAN}

Berdasarkan hasil penelitian ini bahan perawatan gigi dan mulut yang paling banyak dilakukan masyarakat adalah skeling, pencabutan gigi, dan penumpatan. Pada BKGN tahun 2013 perawatan yang dilakukan meliputi pencabutan gigi sulung sebanyak 176 kasus, pencabutan gigi permanen sebanyak 305 kasus, skeling sebanyak 685 kasus, penumpatan resin komposit sebanyak 135 kasus, dan penumpatan GIC sebanyak 162, fissure sealant sebanyak 33 kasus, aplikasi topikal fluor sebanyak 64 kasus, dental health education sebanyak 321, penumpatan sederhana sebanyak 14 kasus, screening sebanyak 69 kasus.

Perawatan yang paling banyak ditangani dalam BKGN tahun 2013 adalah skeling dengan persentase $34,88 \%$. Skeling bertujuan membersihkan semua deposit pada gigi, kalkulus subgingiva, kalkulus supragingiva, plak, dan noda. Skeling harus dilakukan secara menyeluruh. Inflamasi akan menetap bila deposit gigi tidak dibersihkan seluruhnya. ${ }^{3}$ Tingginya jenis perawatan skeling pada BKGN karena masyarakat yang berada di Manado sudah peduli terhadap pentinnya kebersihan gigi dan mulut, dan perawatan ini diberikan secara gratis sehingga masyarakat tertarik untuk melakukan perawatan skeling dibandingankan perawatan skeling pada tempat praktek dokter gigi yang umumnya relaltif mahal.

Pencabutan gigi merupakan kasus terbanyak kedua yang ditemui pada BKGN tahun 2013. Pencabutan gigi merupakan tindakan mengeluarkan gigi dari alveolus. Adapun indikasi gigi yang dicabut merupakan gigi yang berpotensi sebagai focal infection, gigi dengan pulpa nonvital 
yang tidak dapat dirawat dengan perawatan saluran akar, gigi dengan kerusakan periodontal berat, gigi impaksi, gigi supernumerary yang mengganggu, sisa akar, dan gigi dengan malposisi ekstrim. ${ }^{4}$

Tindakan lain terbanyak yang dilakukan pada BKGN 2013 yaitu penumpatan. Penumpatan merupakan suatu tindakan perawatan dengan meletakkan bahan tumpatan pada karies gigi yang telah dibersihkan. Perawatan karies gigi tergantung pada seberapa besar tingkat kerusakan gigi. Penumpatan gigi dilakukan pada gigi sulung menggunakan bahan GIC dan pada gigi permanen menggunakan bahan resin komposit dan amalgam, selain itu dilakukan juga penumpatan sementara untuk gigi yang butuh perawatan lanjutan dan tidak selesai dalam satu kali kunjungan. ${ }^{5}$

Aplikasi topikal fluor dilakukan untuk mencegah terjadinya karies dengan mengontrol karies primer dan karies sekunder (terjadi pada gigi yang telah direstorasi). Faktor - faktor yang dapat dipertimbangkan sebelum melakukan aplikasi topikal fluor adalah risiko karies tinggi, sedang, maupun rendah, angka kariogenik, umur pasien, kandungan fluor dalam air yang sering dikonsumsi dan kondisi sistemik pasien.

Fissure sealant dilakukan pada semua gigi molar permanen pada anak-anak dengan risiko karies sedang hingga tinggi, pada anak-anak dengan risiko karies rendah anak hanya fissure yang dalam dan retentif yang perlu dilakukan fissure sealant dan pada gigi sulung posterior pada anak-anak dengan risiko karies tinggi. Selain mencegah karies, perawatan fissure sealant juga dapat melindungi gigi dari proses karies yang baru dimulai. Perawatan ini sebaiknya dimulai sedini mungkin, yaitu ketika permukaan oklusal gigi bebas dari jaringan gingiva sampai setelah empat tahun gigi erupsi. $^{5}$

Dental Health Education pada BKGN 2013321 sampel, dan screening tanpa perawatan yang hanya ditemukan pada BKGN periode tahun 2013 dengan jumlah 69 kasus. Hal ini terjadi karena kemungkinan pasien tidak berada di lokasi ruang tunggu pada saat nama pasien dipanggil untuk masuk di ruang perawatan.

Berdasarkan kelompok umur pada BKGN periode tahun 2013, umumnya perawatan gigi dan mulut lebih banyak pada kelompok umur $\leq 20$ tahun. Tingginya persentase perawatan gigi dan mulut pada kategori umur $\leq 20$ tahun dapat dikarenakan kurangnya kesadaran dalam menjaga kebersihan gigi dan mulut. Orang tua sangat berperan penting dalam membantu memberikan arahan tentang pentingnya menjaga kesehatan gigi dan mulut pada anak semenjak dini, dengan cara rajin menyikat gigi dan memeriksakan gigi dengan rutin setiap enam bulan sekali ke dokter gigi.

Berdasarkan jenis kelamin pada BKGN periode tahun 2013, umumnya persentase perawatan gigi dan mulut pada perempuan lebih banyak dibandingkan dengan laki-laki, yaitu 1240 perempuan 63,14\% dan 724 laki-laki 36,86\%. Hal ini menunjukkan perempuan lebih peduli akan kesehatan gigi dan mulutnya.

Berdasarkan jenis pekerjaan pada BKGN periode tahun 2013, mayoritas pasien yang berkunjung ialah pelajar/mahasiswa dengan persentase 59,98\%. Hal ini dapat dikarenakan kurangnya kesadaran pelajar/mahasiswa untuk memeriksakan giginya ke dokter gigi atau dapat dikarenakan biaya perawatan gigi dan mulut yang cukup tinggi.

\section{SIMPULAN}

1. Persentase perawatan gigi dan mulut menurut jenis kelamin pada BKGN periode tahun 2013 menunjukkan jenis kelamin perempuan lebih tinggi daripada laki-laki.

2. Persentase perawatan gigi dan mulut menurut kelompok umur pada BKGN periode tahun 2013 menunjukkan kelompok umur $\leq 20$ tahun lebih tinggi daripada kelompok umur lainnya.

3. Perawatan gigi dan mulut terbanyak pada BKGN periode tahun 2013 yaitu skeling sedangkan yang paling sedikit yaitu penumpatan sementara. 


\section{SARAN}

Hasil penelitian ini kiranya dapat digunakan sebagai informasi dan bahan evaluasi untuk meningkatkan pelayanan perawatan gigi dan mulut pada BKGN periode berikutnya, dan bagi operator agar dapat memperhatikan pengisian rekam medik dengan tepat dan benar.

\section{DAFTAR PUSTAKA}

1. Jose O, Cortes G, Carlo E, Solis M, Juan P, Jorge A et al. Dental caries experience, prevalence and Severity in Mexican adolescents and young adults. Mexico: Sauld Publica, 2009; p. $83-84$.

2. Kementrian Kesehatan RI. Situasi kesehatan gigi dan mulut. Jakarta: Infodatin, 2014; p. 1-8.

3. Manson JD, Eley BM. Buku ajar periodonti. Jakarta: Hipokrates. 1993. p. 148.

4. Bakar A. Kedokteran gigi klinis Ed 2. Yogyakarta: Quantum, 2013.

5. Marhaban AIA, Mintjelungan C, Supit A. Gambaran tumpatan amalgam dan semen ionomer kaca pada masyarakat kelurahan kalumpang kecamatan Ternate Tengah. Jurnal Biomedik. 2013;5(1):158-62. 